\title{
ANALYSIS OF TRANSLATION TECHNIQUES AND QUALITY OF TRANSLATED TERMS OF MECHANICAL ENGINEERING IN ACCREDITED NATIONAL JOURNALS
}

\author{
Mohammad Febryanto $^{1}$, Iis Sulyaningsih ${ }^{2}$, Alliyah Anggarani Zhafirah ${ }^{3}$ \\ Politeknik Negeri Bandung \\ 11e1m.febryanto@polban.ac.id, ${ }^{2}$ iis.sulyaningsih@polban.ac.id, \\ ${ }^{3}$ alliyah.anggarani.bing17@polban.ac.id
}

\begin{abstract}
This study investigates the technique of translating mechanical engineering terms from Indonesian to English in accredited national journal abstracts and the quality of the translation results. Qualitative descriptive is used as a research method. The abstracts taken as data are from the national journals accredited in 2019 and 2020, consisting of 59 articles. In collecting data, document analysis is used as a tool to collect data. The results showed that adaptation techniques, common equivalent techniques, literal translation techniques, calque techniques, and pure borrowing techniques are techniques used in translating mechanical engineering terms, and the average value of the quality of the translation results is good.
\end{abstract}

Keywords: Translation Techniques, Translation Quality, Mechanical Engineering Terms

\section{INTRODUCTION}

At this time, science and technology have developed rapidly. It can be seen with the many innovations and new tools being developed. In addition, according to https://www.worldometers.info/books/, which takes data from UNESCO, there are currently $1,199,420$ books around the world that have been published. This phenomenon will indirectly lead to the development of new languages or terms in each field. Therefore, currently, the translator has an essential role in disseminating the development of science by transferring it to the target language. The role of the translator is beneficial and is one of the solutions for readers to understand the development of science, especially for readers whose skills in foreign languages are limited.

Even though it is one of the solutions in the spread of knowledge, translators will have their challenges in translating from the source language to the target language. One of the challenges faced by translators is new terms or specific terms in certain fields such as engineering or technology terms. There are times when a translator faces difficulty in finding the equivalence of words from the source language to the target language. It is as stated by (Newmark, 1981) that translation is an effort to divert a written message from the source language to the target language by prioritizing similar meanings.

The success of a translator on the results of his translation is determined by himself. Therefore, a translator must have competent abilities in both source and target languages. One of its abilities is to understand the meaning of the text from the source language and understand equivalent words in the target language so that the translation results can be read naturally and easily understood by readers, for example, in translating technical terms. A translator must 
grasp the meaning of specific technical terms when translating. The translator can choose words that have appropriate meanings and can be understood in the target language.

Translation techniques are one of the topics in research in the field of translation. This topic is always interesting because the use of translation techniques will always be different when one translates one text to another and one term to another. Until now, there have been several studies examining the translation of technical terms. The first research describes the challenges and difficulties in translating engineering terms. Postolea (2016) suggests that special translators have responsibility for the source text and the target text because the source text's status may be higher than most other types of text. In the field of knowledge, accuracy is a prerequisite, the wrong translation of terms can have terrible results, and the translator must also have responsibility for the target language. Meanwhile, the research results from Раджабова (2017) show that the preparedness of a translator is expressed in the ability to use linguistic and technical information sources and to find the right solution to difficulties, and also in the ability to use accumulated practical experience.

Other research related to translation techniques that translate technical terms is in religion (Yulianita, 2017). The study aims to find the category of religious terms in the translation techniques used to translate them and the accuracy of translation in understanding Islam. The results show that there are fourteen categories of religious terms in this book, namely eschatology, moral and ethical criteria, religious artifacts, religious constructions, religious events, religious groups, religious figures, religious sites, special religious activities, supernatural beings, revelation provisions, religious ceremonies, religious history, and religious activities. In addition, translators use equivalents, loans, literals, particularization, generalization, transposition, reduction, addition, translation, and predefined discursive creation techniques. And the average score for translation accuracy is 2.8. Another field related to medicine is Widarwati (2015). This study aims to compile a taxonomy and to identify and describe the translation techniques used in translating medical terms in relation to the quality of their translation. The results of this study indicate that there is a pattern of transferring medical terms in the form of taxonomy.

In addition, there are seven translation techniques in translating medical terms, which have a positive impact on the accuracy, acceptability, and readability of the translation. And finally is Hassan (2017) in the computer field. The main objective of his research is to explore the techniques used in translating English technical terms into Arabic in the Microsoft Terminology Collection (MTC) (English-Arabic) as an example of a comprehensive multilingual resource of technical terminology on the Web. The study reports that it is more proper to use Arabic translation and/or extension techniques with technical terms derived from language roots in the source language to maintain the integrity and authenticity of Arabic as the target language. Meanwhile, the Arabization method may only be used with an appropriate source language noun or any word derived from the source language to solve non-equivalence problems at the word level between Arabic and English.

In addition, at this time, there have been many journal articles published with abstracts in two versions, namely Indonesian and English. This situation allows for the translation process to occur, considering that in Indonesia, English is a foreign language. Therefore this research concentrates more on looking at translation techniques from Indonesian to English and the quality of the translation results on mechanical engineering terms contained in the abstracts of nationally accredited journals. 


\section{LITERATURE REVIEW}

\section{Translation}

House (2015) states that translation is an activity of text processing and text reproduction that leads from the source text to the resulting text. In contrast, Munday (2016) sees that the meaning of translation currently includes three aspects, namely (1) general subject areas or phenomena, (2) products - namely, text that has been, and (3) the process of producing a translation, otherwise known as translating. Osman (2017) sees that translation is a mental activity in which the meaning of linguistic discourse is given from one language to another. This is the act of transferring a linguistic entity from one language to its equivalent to another. Meanwhile, Malmkjær (2017) defines translation as a process or product in the original text replaced by another text that reflects or is inspired by the original entity. Setiawan (2020) states that translation is an attempt to get the meaning of one language (usually a foreign language) so that the substance can be conveyed to another language (target language).

Nida \& Taber (1982) state that the translation process consists of three stages, namely (1) Analysis of the linguistic structure in terms of the relationship between grammar and the meaning of words, (2) Transfer of the material analyzed in the mind of the translator to be transferred from the source language to target language, (3) restructuring, the material that has been analyzed is restructured to make a final message that can be received in the target language. Meanwhile, (Newmark, 1988) describes the translation process starting with choosing a translation method. Second, when translating, four levels need attention, namely: (1) The level of the source language text, (2) The referential level, (3). Cohesive level, (4). Natural level. Then Robinson (1997) formulated the translation process by translating intuitively then editing after that sublimating. Meanwhile, Bell \& Candlin (1991) recommend two phases of the translation process, namely (1) Analysis of one specific source language text into universal (non-specific language) semantic representations and (2) Synthesis of that semantic representation into specific target language texts. Hansen (2003) sees that the translation process is everything that happens, from the time the translator starts working on the source text until he finishes the target text. They cover, from every pencil move to the use of all kinds of tools, and the entire process involved in making decisions, solving problems, and making corrections.

\section{Translation Techniques}

Molina \& Albir (2002) define translation techniques as procedures for analyzing and classifying how translation equivalence occurs and can be applied to various lingual units. The suggested translation techniques are:

\section{a. Adaptation}

This technique replaces the typical terms of the source language text with other terms accepted and recognized in the target language.

b. Amplification

This technique introduces/adds detailed information not contained in the source language text, namely explicit paraphrasing or explanations.

\section{c. Borrowing}

Take a word or expression directly from the source language. This direct borrowing is called pure borrowing, while borrowing that uses the adaptation of the phonetic system and the target language's morphology is naturalized borrowing.

d. Calque

The literal translation of a word or phrase from the source language directly into the target language can be at the lexical or structural level. 
e. Compensation

Introducing information elements of the source language text or stylistic effects that are found at other positions in the target language text, as they cannot be reflected at the same position in the source-language text.

f. Description

Replace terms or expressions with descriptions of their form and function.

g. Discursive Creation

Specify temporary equivalents that were unexpected or out of context.

h. Established Equivalent

Using terms or expressions that are recognized / common (based on dictionaries or colloquial usage).

i. Generalization

Use more general or neutral terms in the target language.

j. Linguistic Amplification

Add linguistic elements. This technique is often used in consecutive oral translation and dubbing.

k. Linguistic Compression

Gather and make one linguistic element in the target language text. This technique is often used in spontaneous oral translation and subtitling.

1. iteral translation

Translate a word or phrase word for word.

m. Modulation

Substituting a point of view, focus, or cognitive category concerning the source-language text.

It can be at the lexical or structural level.

n. Particularization

Use more concrete or specific terms. Contrary to generalization techniques.

o. Reduction

Press/compress the source language text information feature into the target language text.

p. Substitution

Replacing linguistic elements into paralinguistic elements or vice versa.

q. transposition

Change the grammatical category.

r. Variation

Replacing linguistic or paralinguistic elements (intonation, gesture) that have an impact on linguistic variation.

\section{Assessment of the quality of the translation results}

The translated text is required to have good quality to make no mistakes in expressing the meaning in the target language. There are three criteria for assessing the quality of a translation result - accuracy, readability, and acceptability (Nababan \& Nuraeni, 2012)

Accuracy

The quality of a translated text is said to be of quality if the text can present messages contained in the source language equivalent to the target language. The meaning between the source language and the target language is equivalent because the message is conveyed on target. The message from the source language has the same information.

Readability 
Ideally, the translated text has an easy level of understanding and reading (Nababan \& Nuraeni, 2012). Therefore the translation result must have a good readability level to understand the sentence even though he does not know the original text.

\section{Acceptability}

Acceptance means that the translation results can naturally match the target language. An acceptable translation text can be said that the text is no longer like the translated text. The purpose of acceptance is that the translated text has met the existing rules in the target language.

\section{METHOD}

This research design is descriptive. This study focuses on analyzing abstract Indonesian and English versions. Abstracts are taken from the National Journal of mechanical engineering indexed by Sinta 3-5. SINTEK JURNAL: Sinta 3 indexed Mechanical Engineering Scientific Journal, Sinta 4 indexed Vocational Dynamics Journal of Mechanical Engineering, Sinta 5 indexed Mechanical Engineering Study Journal was chosen as the national accredited journal. The abstracts taken as data were the research results in 2019 and 2020 as many as 59 articles. The data in this study were technical terms in the form of words or phrases. Data taken from data sources were then validated based on predetermined criteria. Data translation was a translation technique used by translators to translate technical terms in the source language text into the target language text.

The data contained in the technical terms were collected using content analysis, by reading the entire text and labeling the technical terms in the source language text, and then finding the translation in the target language text. In this study, the translation techniques developed by Molina and Albir are a reference source in determining translation techniques. Furthermore, data about the quality of the translation will be evaluated by a certified translator.

The data obtained are categorized as technical terms and then grouped based on translation techniques and translation quality. Finally, conclusions are drawn based on the research objectives.

\section{RESULTS AND DISCUSSION}

\section{Results}

In the three research data journals, 292 mechanical engineering terms can be identified. With the details of each journal: Sintek Journal with 113 terms, Dynamics Journal with 49 terms, and Mechanical Engineering Study Journal with 131 terms (see attachment). The translation techniques found in this study were 28 adaptation techniques, 34 common equivalent techniques, 179 literal translation techniques, six calque techniques, and 48 pure borrowing techniques. Detailed data can be seen in the table below.

Table 1. Translation techniques

\begin{tabular}{llcccc}
\hline \multirow{2}{*}{ No } & Translation techniques & Sintek & Dinamika & $\begin{array}{c}\text { Kajian Teknik } \\
\text { Mesin }\end{array}$ & Total \\
\cline { 3 - 5 } & 5 & 9 & 13 & 28 \\
\hline 1. & Adaptation technique & 15 & 0 & 19 & 34 \\
\hline 2. & $\begin{array}{l}\text { Common equivalent } \\
\text { technique }\end{array}$ & & &
\end{tabular}




\begin{tabular}{clcccc}
\hline 3. & Literal translation technique & 72 & 27 & 80 & 179 \\
\hline 4. & Calque technique & 3 & 1 & 1 & 6 \\
\hline 5. & Pure borrowing technique & 17 & 9 & 17 & 45 \\
\hline
\end{tabular}

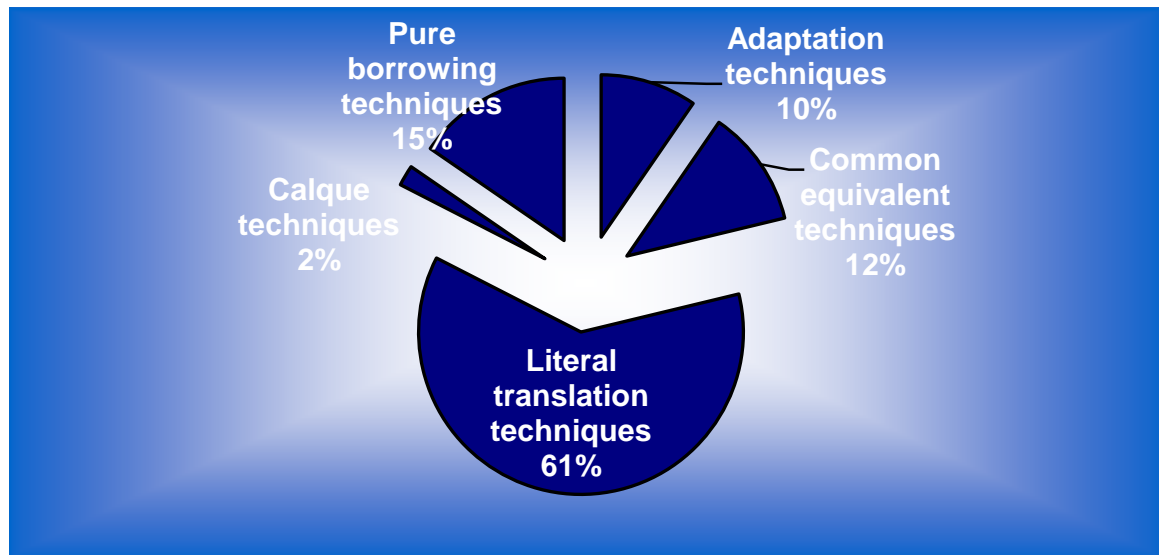

Figure 1. Percentage of translation techniques

The diagram above shows that the literal technique is the most widely used, about $61 \%$. The pure borrowing technique is $15 \%$. The common equivalent technique is $12 \%$, followed by the adaptation technique by $10 \%$. Finally, the calque technique is $2 \%$.

In assessing the quality of the translation results, the study used an assessment aspect developed by (Nababan \& Nuraeni, 2012). The assessment aspects include readability, accuracy, and acceptability. The quality of the translation of mechanical engineering terms is assessed by a certified translator who is familiar with translating the engineering field. The results of the assessment are as follows.

Table 2 The score of quality of the translation

\begin{tabular}{|c|c|c|c|c|c|}
\hline \multirow[b]{2}{*}{ No } & \multirow[b]{2}{*}{ Translation techniques } & \multicolumn{3}{|c|}{ Quality } & \multirow[b]{2}{*}{$\begin{array}{c}\text { Mean } \\
\text { total } \\
\text { score }\end{array}$} \\
\hline & & $\begin{array}{c}\text { Mean } \\
\text { score of } \\
\text { accuracy }\end{array}$ & $\begin{array}{l}\text { Mean score of } \\
\text { acceptability }\end{array}$ & $\begin{array}{l}\text { Mean score of } \\
\text { readability }\end{array}$ & \\
\hline 1. & Adaptation technique & 3 & 3 & 3 & 9 \\
\hline 2. & $\begin{array}{l}\text { Common equivalent } \\
\text { technique }\end{array}$ & 3 & 3 & 3 & 9 \\
\hline 3. & $\begin{array}{ll}\text { Literal } & \text { translation } \\
\text { technique } & \end{array}$ & 2.99 & 2.99 & 2.99 & 8.98 \\
\hline 4. & Calque technique & 3 & 3 & 3 & 9 \\
\hline 5. & Pure borrowing technique & 2.98 & 2.98 & 2.98 & 8.93 \\
\hline
\end{tabular}

Table 2 above shows that the average value of the translation results' quality for adaptation techniques, calque technique techniques, and common equivalent techniques is 3 . It means that each aspect has a maximum value of 3 , and the average value for the whole is 9 . However, the average value of the quality of the translation results for the pure borrowing technique is 2.98 , with the average value for the whole is 8.93 . And the average value of the quality of the 
translation results for literal translation techniques is 2.99 , and the average value for the whole is 8.98 .

\section{Discussion}

The selection of a translation technique will determine the translation results from the source language to the target language. The right translation technique also determines the acceptability, accuracy, and readability of the translated mechanical engineering terms. Based on the findings that literal translation techniques are more widely used as a translation technique in translating mechanical engineering terms.

Table 3 Example of Literal translation technique

\begin{tabular}{lllll} 
No & No Data & Indonesian Terms & English Terms & \multicolumn{1}{c}{$\begin{array}{c}\text { Translation } \\
\text { techniques }\end{array}$} \\
\hline 1 & ITM010 & $\begin{array}{l}\text { produktifitas } \\
\text { pengeringan }\end{array}$ & drying productivity & $\begin{array}{l}\text { Literal translation } \\
\text { technique }\end{array}$ \\
\hline 2 & ITM011 & aliran searah & directional flow & $\begin{array}{l}\text { Literal translation } \\
\text { technique }\end{array}$ \\
\hline 3 & ITM017 & aliran fluida pemanas & heating fluid flow & $\begin{array}{l}\text { Literal translation } \\
\text { technique }\end{array}$ \\
\hline 4 & ITM027 & kabut atau butiran & mist or granules & $\begin{array}{l}\text { Literal translation } \\
\text { technique }\end{array}$ \\
\hline
\end{tabular}

The table above is an example of a translation technique. It can be seen that when translating technical terms in Indonesian into English by translating word for word. For example, if you look at ITM027 data kabut atau butiran, kabut $=$ mist, atau = or, and butiran = granules. Molina \& Albir (2002)r said that the technique of translating a word or phrase word for word. From the example above, the translator translates every word of the source language into the target language.

The second translation technique discovered was pure borrowing technique. There are 45 pieces or $15 \%$ use of this technique in translating mechanical engineering terms. The following table contains examples of translation using pure borrowing techniques.

Table 4 Example of Pure borrowing technique

\begin{tabular}{lllll}
\hline No & $\begin{array}{c}\text { No } \\
\text { Data }\end{array}$ & Indonesian Terms & English Terms & \multicolumn{1}{c}{$\begin{array}{c}\text { Translation } \\
\text { techniques }\end{array}$} \\
\hline 1 & ITM129 & $\begin{array}{l}\text { Minimum Quantity } \\
\text { Lubrication }\end{array}$ & $\begin{array}{l}\text { Minimum Quantity } \\
\text { Lubrication }\end{array}$ & $\begin{array}{l}\text { Pure borrowing } \\
\text { technique }\end{array}$ \\
\hline 2 & ITM134 & sheet metal & sheet metal & $\begin{array}{l}\text { Pure borrowing } \\
\text { technique }\end{array}$ \\
\hline 3 & ITM047 & clutch disc & clutch disc & $\begin{array}{l}\text { Pure borrowing } \\
\text { technique }\end{array}$ \\
\hline 4 & ITM013 & baffle & baffle & $\begin{array}{l}\text { Pure borrowing } \\
\text { technique }\end{array}$ \\
\hline 5 & ITM021 & engine dan frame & engine and frame & $\begin{array}{l}\text { Pure borrowing } \\
\text { technique }\end{array}$ \\
\hline
\end{tabular}


Based on the table above, there are similarities in terms of both in Indonesian and in English. According to Molina \& Albir (2002), if a translator takes a word or expression directly from the source language, this direct borrowing is called pure borrowing. For example, ITM047 clutch disc data, ITM 134 sheet metal, and others. The translator uses the name of the term in both Indonesian and English. This means that the translator borrows a phrase or term directly from the target language to the source language. However, something is interesting about using technical term names in the source language or Indonesian, which are actually English terms. It can be said that the translator did not translate the terms. There are several reasons why this happens, such as the author prefers to use the term in English even though it is written in the Indonesian context, or maybe the term does not have an equivalent in Indonesian, so the translator uses the term in English.

Table 5 Example of Common equivalent technique

\begin{tabular}{lllll} 
No & No Data & Indonesian Terms & English Terms & \multicolumn{1}{c}{$\begin{array}{c}\text { Translation } \\
\text { techniques }\end{array}$} \\
\hline 1 & ITM001 & Dual Translasional & Dual Translational & $\begin{array}{l}\text { Common equivalent } \\
\text { technique }\end{array}$ \\
\hline 2 & ITM005 & eksitasi & excitation & $\begin{array}{l}\text { Common equivalent } \\
\text { technique }\end{array}$ \\
\hline 3 & ITM038 & poliuretan & polyurethan & $\begin{array}{l}\text { Common equivalent } \\
\text { technique }\end{array}$ \\
\hline 4 & ITM042 & transmisi & transmission & $\begin{array}{l}\text { Common equivalent } \\
\text { technique }\end{array}$ \\
\hline 5 & ITM179 & chasis defleksi & chassis deflection & $\begin{array}{l}\text { Common equivalent } \\
\text { technique }\end{array}$ \\
\hline
\end{tabular}

The table above is an example of mechanical engineering terms translated using common equivalent techniques. Molina and Albir revealed that the usual equivalent technique is a translation technique that uses terms or expressions that are already recognized/ commonly based on dictionaries or colloquial usage. Transmisi, ITM042 data is translated into transmission. This shows that the word transmission in English has the same word in Indonesian, namely transmisi.

Table 6 Example of Adaptation technique

\begin{tabular}{lllll} 
No & No Data & Indonesian Terms & English Terms & \multicolumn{1}{c}{$\begin{array}{c}\text { Translation } \\
\text { techniques }\end{array}$} \\
\hline 1 & ITM022 & industri perakitan & motorcycle industry & $\begin{array}{l}\text { Adaptation } \\
\text { technique }\end{array}$ \\
\hline 2 & ITM169 & sifat magnet & magnetic properties & $\begin{array}{l}\text { Adaptation } \\
\text { technique }\end{array}$ \\
\hline 3 & ITM193 & palu pemukul & impact hammer & $\begin{array}{l}\text { Adaptation } \\
\text { technique }\end{array}$ \\
\hline 4 & ITM208 & prestasi mesin & engine performance & $\begin{array}{l}\text { Adaptation } \\
\text { technique }\end{array}$ \\
\hline
\end{tabular}




\begin{tabular}{|c|c|c|c|}
\hline 5 & ITM214 irit & economical & $\begin{array}{l}\text { Adaptation } \\
\text { technique }\end{array}$ \\
\hline
\end{tabular}

The above is an example of a mechanical engineering term that is translated using adaptation techniques. Adaptation technique is a technique by replacing the typical terms of the source language text with other accepted terms and known in the target language ((Molina \& Albir, 2002). It can be seen in the ITM022 data on the Indonesian term industri perakitan; the word perakitan is translated into motorcycle. The choice of the word motorcycle by the translator is more appropriate for the equivalent of the word assembly than assembly word, likewise with other terms.

Table 7 Example of Calque technique

\begin{tabular}{lllll}
\hline No & No Data & Indonesian Terms & English Terms & $\begin{array}{l}\text { Translation } \\
\text { techniques }\end{array}$ \\
\hline 1 & ITM065 & bearing poros mesin & engine shaft bearing & $\begin{array}{l}\text { Calque } \\
\text { technique }\end{array}$ \\
\hline 2 & ITM072 & $\begin{array}{l}\text { bahan bakar } \text { Refuse } \\
\text { Derived (RDF) }\end{array}$ & $\begin{array}{l}\text { Refuse Derived Fuel } \\
\text { (RDF) }\end{array}$ & $\begin{array}{l}\text { Calque } \\
\text { technique }\end{array}$ \\
\hline 3 & ITM094 & Pengujian dry gas seal & Dry gas seal testing & $\begin{array}{l}\text { Calque } \\
\text { technique }\end{array}$ \\
\hline 4 & ITM117 & proses manufaktur & $\begin{array}{l}\text { machining and fabrication } \\
\text { process }\end{array}$ & $\begin{array}{l}\text { Calque } \\
\text { technique }\end{array}$ \\
\hline 5 & ITM224 & pin datum & datum pin & $\begin{array}{l}\text { Calque } \\
\text { technique }\end{array}$ \\
\hline
\end{tabular}

The Calque technique is the literal translation of a word or phrase from the source language directly into the target language, either at the lexical or structural level (Molina \& Albir, 2002). For example, in the data table above, the ITM224 data pin datum is translated into English to become a datum pin. The terms in Indonesian are the same as in English, but the translation version has been changed at the structural level.

From the quality of the translation results, all terms of mechanical engineering have been translated into English by the translator are good. The scores given (see table 2) by the rater both as a whole and per aspect shows excellent results. This indicates no need to doubt the acceptability, accuracy, and readability of the translation results into English.

\section{CONCLUSION}

Based on the findings and discussion, first, it can be concluded that there are four types of translation techniques found and used in translating mechanical engineering terms. These techniques are adaptation techniques, common matching techniques, literal translation techniques, Calque technique techniques, and pure borrowing techniques. This indicates that in translating is not necessary to use all translation techniques but according to needs.

Second, based on the mean score, the quality of the translation results is good. This means that the accuracy, acceptability, and readability of mechanical engineering terms in English can be understood by foreigners who read them. 


\section{ACKNOWLEDGMENTS}

This research has been funded by Politeknik Negeri Bandung in 2020 with contract number: Nomor: B/249.3/PL1.R7/PG.00.03/2020.

\section{REFERENCES}

Bell, R. T., \& Candlin, C. (1991). Translation and translating: Theory and practice (Vol. 298). Longman London.

Hansen, G. (2003). Controlling the Process. Theoretical and Methodological Reflections. F. Alves, 25-42.

Hassan, S. S. (2017). Translating technical terms into Arabic: Microsoft terminology collection (English-Arabic) as an example. Translation \& Interpreting, 9(2), 67-86.

House, J. (2015). Translation as communication across languages and cultures. books.google.com.

https://books.google.com/books?hl=en\&lr=\&id=sqPhCgAAQBAJ\&oi=fnd\&pg=PP1\&dq $=$ interpersonal+metafunction+digital+text\&ots $=$ YGApDBWdC8\&sig=pZgXP59Ig4KtuL TzpEsJBFnBWt8

Malmkjær, K. (2017). The Routledge handbook of translation studies and linguistics. Routledge.

Molina, L., \& Albir, A. H. (2002). Translation technique Revisited: A Dynamic and Functionallist Approach. Universitat Autonoma de Barcelona. Meta, XLVII. 4, 2002. Barcelona, Spain: Universitat Autonoma de Barcelona.

Munday, J. (2016). Introducing translation studies: Theories and applications. Routledge.

Nababan, M., \& Nuraeni, A. (2012). Pengembangan model penilaian kualitas terjemahan.

Newmark, P. (1981). Approaches to translation (Vol. 1). Pergamon Press Oxford.

Newmark, P. (1988). A textbook of translation (Vol. 66). Prentice hall New York.

Nida, E. A., \& Taber, C. R. (1982). The theory and practice of translation (Vol. 8). Brill Archive.

Osman, A. (2017). Definition of Translation. Translation Journal.

Раджабова, Д. А. (2017). Difficulties of the translation of scientific and technical texts. Молодой Ученый, 13, 595-599.

Postolea, S. (2016). Translating in a Specialised Context: Challenges and Risks. Bulletin of the Polytechnic Institute of Iasi. Section: Social Sciences, 51-66.

Robinson, D. (1997). Becoming a translator: an accelerated course. Psychology Press.

Setiawan, D. (2020). Analysing the Works of a Machine Translation. International Journal of Language and Literary Studies, 2(2), 230-241.

UNESCO https://www.worldometers.info/books/ retrieved on 13 June, 2020.

Widarwati, N. T. (2015). Taksonomi dan Teknik Penerjemahan Istilah Kedokteran. Prosiding PESAT, 6.

Yulianita, N. G. (2017). Penerjemahan Istilah Religi: Penilaian Kualitas Keakuratan. Adabiyyāt: Jurnal Bahasa Dan Sastra, 1(2), 156-181. 